\title{
EVALUASI ATAS PENERAPAN PP 23 TAHUN 2018 PADA KANTOR PELAYANAN PAJAK PRATAMA KABANJAHE
}

\author{
Agus Bandiyono, Rika Permatasari Simarmata \\ Politeknik Keuangan Negara STAN \\ Email: agusbandiyono@pknstan.ac.id
}

\begin{abstract}
This research was conducted to evaluate the implementation of Government Regulation No. 23/2018 at the Kabanjahe Primary Tax Office and to find out the problems faced in implementing these regulations. The method used in this research is a qualitative method which is carried out by direct interviews with 2 Account Representatives at KPP Pratama Kabanjahe. The results of this study indicate that the implementation of PP 23 of 2018 at KPP Pratama Kabanjahe can be said to be quite effective. This is based on data on taxpayers who pay PPh Final PP 23 which has increased quite significantly. In addition, there was an increase in PPh Final PP 23 deposits throughout 2018 to 2019. Although there was a decrease in the amount of deposits compared to the previous year, this was due to a decrease in rates from $1 \%$ to $0.5 \%$. Although the implementation of PP 23 at KPP Pratama has been quite effective, it does not affect the percentage of taxpayers' compliance, especially corporate taxpayers. Meanwhile, the percentage level of non-entrepreneur individual taxpayer compliance has increased from 2016 to 2019, so it can be concluded that this rule is quite effective in increasing the compliance level of individual taxpayers.
\end{abstract}

Keywords : taxation, effectiveness, tax compliance, income tax, tax revenue

DOI: http://dx.doi.org/10.29040/jap.v22i1.1731

\section{PENDAHULUAN}

Menurut Laporan Kinerja Direktorat Jenderal Pajak tahun 2018 (2019:22), persentase tingkat kepatuhan formal Wajib Pajak Badan dan Orang Pribadi Non Karyawan hanya sebesar 69,30\% sedangkan realisasi WP Badan dan OP Non Karyawan yang melakukan pembayaran hanya sebesar $50,48 \%$. Dapat kita simpulkan bahwa kesadaran Wajib Pajak dalam membayar pajak masih cukup rendah. Faktor lainnya yaitu sulitnya tata cara perhitungan dan perbedaan tarif pajak untuk objek yang berbeda.

Menyikapi hal tersebut, pemerintah melalui Menteri Keuangan berupaya untuk membantu Wajib Pajak agar dapat menjalankan kewajiban perpajakannya. Adapun kegiatan yang dilakukan adalah menyederhanakan beberapa formulir dan aturan. Dalam rangka menyederhanakan aturan untuk pengenaan Pajak Penghasilan untuk Orang Pribadi Usahawan. Pemerintah mengesahkan aturan Peraturan Pemerintah Nomor 46 Tahun 2013 tentang Pajak Penghasilan Atas Penghasilan dari Usaha Yang Diterima atau Diperoleh Wajib Pajak yang Memiliki Peredaran Bruto Tertentu. Peraturan tersebut dibuat dengan menimbang untuk memberikan kemudahan kepada Wajib Pajak orang pribadi dan badan yang memiliki peredaran bruto tertentu, sehingga perlu memberikan perlakuan tersendiri ketentuan mengenai penghitungan, penyetoran, dan pelaporan Pajak Penghasilan yang terutang. Hal tersebut bertujuan untuk memberikan kemudahan dan penyederhanaan aturan perpajakan, mengedukasi masyarakat untuk tertib administrasi, mengedukasi masyarakat untuk transparansi, dan memberikan kesempatan untuk berkontribusi dalam penyelenggaraan negara hanya dengan membayar pajak dengan tarif $1 \%$ dari peredaran bruto. Tarif $1 \%$ ini sangatlah ringan dalam perhitungan pembayaran pajak yang hanya dikalikan dengan omzet bruto, 
ditambah lagi PP 462013 ini bersifat pajak final yang apabila setelah kewajiban perhitungan, penyetoran dan pembayarannya sudah terpenuhi maka tugas dari Wajib Pajak sudah selesai (Suryani, dkk., 2019).

Kelanjutan dari aturan tersebut adalah pengesahan Peraturan Pemerintah Nomor 23 Tahun 2018 dimana tarif pajak untuk Orang Pribadi Usahawan diturunkan menjadi $0,5 \%$. Tujuan dari pengesahan aturan tersebut adalah sebagai bentuk evaluasi dari PP 46 Tahun 2013. Perubahan yang terjadi adalah penurunan tarif, penambahan jangka waktu, hak memilih menggunakan PP 23 ataupun angsuran Pasal 25, tambahan pengecualian subjek pajak dan tata cara penyetoran.

Penelitian ini memiliki 2 tujuan diantaranya adalah mengevaluasi PP 23 Tahun 2018 dan mengidentifikasi masalah yang terjadi dalam rangka penerapan aturan tersebut. Sistematika penulisan disusun sebagai berikut: pertama tinjauan pustaka yang menjelaskan tentang PP 23 Tahun 2018, kemudian dijabarkan tentang data penerimaan serta masalah terkait penerapan aturan tersebut. Bagian selanjutnya menyajikan tentang pembahasan, dan bagian akhir menyajikan kesimpulan dan saran terkait penelitian.

\section{Tinjauan Pustaka}

Dalam Buku Lebih Dekat dengan Pajak (2009:04), jenis-jenis pajak yang dikelola oleh pemerintah pusat dalam hal ini adalah Direktorat Jenderal Pajak, yaitu PPN, PPh, PPnBM, PBB P3 dan Bea Materai. Wajib Pajak usahawan melakukan kegiatan usaha dan mendapatkan tambahan ekonomi berupa penghasilan sehingga atas penghasilan tersebut dikenakan pajak berupa pajak penghasilan. Dalam Undang-Undang Nomor 36 Tahun 2008 tentang Pajak Penghasilan, Pajak Penghasilan (PPh) adalah pajak yang dikenakan kepada orang pribadi atau badan atas penghasilan yang diterima atau diperoleh dalam suatu tahun pajak. Sehingga yang menjadi objek dalam pajak ini, adalah penghasilan yang diterima oleh Orang Pribadi atau Badan. Adapun jenis-jenis pajak penghasilan adalah PPh Pasal 15, PPh Pasal 19, PPh Pasal 21, PPh Pasal 25, PPh Pasal 29 dan PPh Final Pasal 4 ayat 2. Perbedaan dari jenis pajak tersebut adalah objek dari pajak yang dikenakan. Wajib Pajak yang berkewajiban untuk membayar pajak atas penghasilan dari usaha pada awalnya membayar PPh Pasal 25 dengan menggunakan Norma Perhitungan Penghasilan Neto (NPPN) dengan cara membayarkan secara mengangsur. Namun, pada tahun 2013 diterbitkan aturan baru yaitu Peraturan Pemerintah Nomor 46 Tahun 2013 tentang Pajak Penghasilan dari Usaha yang Diterima atau Diperoleh Wajib Pajak yang Memiliki Peredaran Bruto Tertentu. Dengan disahkannya aturan ini, Wajib Pajak yang memenuhi syarat dikenakan pajak penghasilan dengan tarif $1 \%$ dan bersifat final. Adapun syarat tersebut dimuat dalam Pasal 2 ayat (2) yaitu Wajib Pajak tidak termasuk Bentuk Usaha Tetap (BUT) dan menerima penghasilan dari usaha, tidak termasuk penghasilan dari jasa sehubungan dengan pekerjaan bebas, dengan peredaran bruto tidak melebihi $\mathrm{Rp}$ 4.800.000.000,00 (empat miliar delapan ratus juta rupiah) dalam 1 (satu) Tahun Pajak.

Setelah disahkannya aturan PP 46 Tahun 2013, pemerintah kemudian menerbitkan aturan baru yaitu Peraturan Pemerintah Nomor 23 Tahun 2018. Tujuan disahkannya aturan tersebut adalah untuk mendorong masyarakat berperan serta dalam ekonomi formal, dengan memberikan kemudahan dan lebih berkeadilan kepada Wajib Pajak yang memiliki peredaran bruto tertentu dalam jangka waktu tertentu. Subjek pajak dari PP 23 tahun 2018 adalah Wajib Pajak orang pribadi dan Wajib Pajak badan berbentuk koperasi, persekutuan komanditer, firma, atau perseroan terbatas. Namun peraturan ini membatasi jenis Wajib Pajak yang dapat menggunakan aturan tersebut, yaitu Wajib Pajak memilih untuk dikenai Pajak Penghasilan berdasarkan tarif Pasal 17 ayat (1) huruf a, Pasal 17 ayat (2a), atau Pasal 3lE Undang-Undang Pajak Penghasilan, Wajib Pajak badan berbentuk persekutuan komanditer atau firma yang dibentuk oleh beberapa Wajib Pajak orang pribadi yang memiliki keahlian khusus menyerahkan jasa sejenis dengan jasa sehubungan dengan pekerjaan bebas sebagaimana dimaksud dalam Pasal 2 ayat (4), dan Wajib Pajak badan memperoleh fasilitas Pajak Penghasilan berdasarkan Pasal 31A Undang-Undang Pajak Penghasilan atau 
Peraturan Pemerintah Nomor 94 Tahun 2010, dan Wajib Pajak berbentuk Bentuk Usaha Tetap.

Objek dari PP 23 adalah seluruh penghasilan dari usaha yang diterima atau diperoleh Wajib Pajak dalam negeri yang memiliki peredaran bruto tertentu. Perbedaan mendasar dari PP 23 dan PP 46 adalah adanya perubahan tarif yang cukup signifikan. Tarif PP 23 Tahun 2018 adalah 0,5\% dari penghasilan bruto dan bersifat final. Adapun besaran penghasilan bruto yang dijadikan dasar pengenaan pajak adalah imbalan atau nilai pengganti berupa uang atau nilai uang yang diterima atau diperoleh dari usaha, sebelum dikurangi potongan penjualan, potongan tunai, dan/atau potongan sejenis. Pajak penghasilan yang telah dihitung dapat dilunasi dengan cara disetor sendiri, dipotong atau dipungut.

Pelaporan pajak atas PP 232018 dilakukan sama seperti PP 46 yaitu menggunakan SPT Tahunan 1770 dimana perhitungan PP 23 yang telah dibayar per bulannya dilampirkan di akhir dan dipisahkan untuk setiap cabang. Sedangkan total nilainya dimasukkan ke lembar III pada jenis penghasilan lain yang dikenakan pajak final dan/atau bersifat final.

Adapun ketentuan lain yang membedakan PP 23 dari PP 46 adalah adanya jangka waktu penggunakan PP 23 yaitu paling lama 7 ahun Pajak bagi Wajib Pajak orang pribadi, 4 Tahun Pajak bagi Wajib Pajak badan berbentuk koperasi, persekutuan komanditer, atau firma, dan 3 Tahun Pajak bagi Wajib Pajak badan berbentuk perseroan terbatas. Jangka waktu tersebut terhitung sejak tahun pajak Wajib Pajak terdaftar apabila Wajib Pajak terdaftar setelah tahun 2018 atau sejak tahun 2018 apabila Wajib Pajak terdaftar sebelum tahun 2018.

Menurut Siti Kurnia Rahayu (2010;138), kepatuhan Wajib Pajak dapat didefinisikan sebagai suatu keadaan dimana Wajib Pajak memenuhi semua kewajiban perpajakan dan melaksanakan hak perpajakannya.Sedangkan menurut Jotopurnomo, C., \& Mangoting, Y. (2013), kepatuhan pajak adalah suatu keadaan saat Wajib Pajak paham atau berusaha untuk memahami semua ketentuan peraturan perundang undangan perpajakan, mengisi formulir pajak dengan lengkap dan jelas, menghitung jumlah pajak yang terutang dengan benar, dan membayar pajak yang terutang tepat pada waktunya. Kepatuhan Wajib Pajak dapat digunakan dalam rangka mengukur partisipasi masyarakat dalam menjalankan kewajiban perpajakannya. Apabila tingkat kepatuhan Wajib Pajak cukup tinggi, hal tersebut menunjukkan bahwa sistem self assessment telah dilaksanakan dengan optimal, sedangkan apabila tingkat kepatuhan Wajib Pajak cukup rendah, disebabkan oleh rendahnya kesadaran masyarakat dalam menjalankan kewajiban perpajakannya.

\section{METODE PENELITIAN}

Metode yang digunakan dalam penelitian ini adalah metode kualitatif yang dilakukan dengan cara wawancara langsung dengan 2 orang Account Representative di KPP Pratama Kabanjahe berdasarkan data hasil pengolahan data penerimaan. Adapun pertanyaan secara garis besar meliputi jumlah penerimaan yang mengalami kenaikan dan penurunan, jumlah Wajib Pajak yang melakukan pembayaran, dan masalah yang dihadapi dalam rangka penerapan aturan PP 23 di KPP Pratama Kabanjahe.

\section{HASIL DAN PEMBAHASAN 3.1. Hasil Penelitian}

\section{Evaluasi atas penerapan PP 23 Tahun 2018 di KPP Pratama Kabanjahe}

Dalam rangka mencapai target penerimaan atas PPh Final PP 23 Tahun 2018 di KPP Pratama Kabanjahe, Seksi Ekstensifikasi bersama dengan Seksi Pengawasan dan Konsultasi melakukan kegiatan dalam rangka memperkenalkan aturan tersebut kepada Wajib Pajak. Berdasarkan hasil wawancara yang dilakukan dengan Account Representative (AR) Seksi Ekstensifikasi dan Penyuluhan, BapakSabar Johannes menjelaskan kegiatan dalam rangka memberikan edukasi kepada Wajib Pajak. Kegiatan tersebut berupa sosialisasi kepada Wajib Pajak yaitu UMKM, pemberian leaflet pajak, pembagian brosur, pemasangan spanduk dan baliho serta pemberian infomasi dan konsultasi kepada calon Wajib Pajak baru yang hendak memiliki NPWP. Kegiatan ini diharapkan dapat membantu Wajib Pajak untuk memahami aturan tersebut secara menyeluruh 
dan sehingga Wajib Pajak dapat menjalankan kewajiban perpajakannya secara benar. Untuk melihat apakah Wajib Pajak telah mengetahui tentang peraturan tersebut, maka dapat dilihat melalui jumlah Wajib Pajak yang melakukan pembayaran PPh Final PP 23 di KPP Pratama Kabanjahe.Grafik 4.1 menjelaskan tentang perkembangan Wajib Pajak Orang Pribadi yang melakukan pembayaran PPh Final PP 23 Tahun 2018.

Grafik 4.1 Wajib Pajak Orang Pribadi yang Melakukan Pembayaran

PPh Final PP 23 di KPP Pratama Kabanjahe

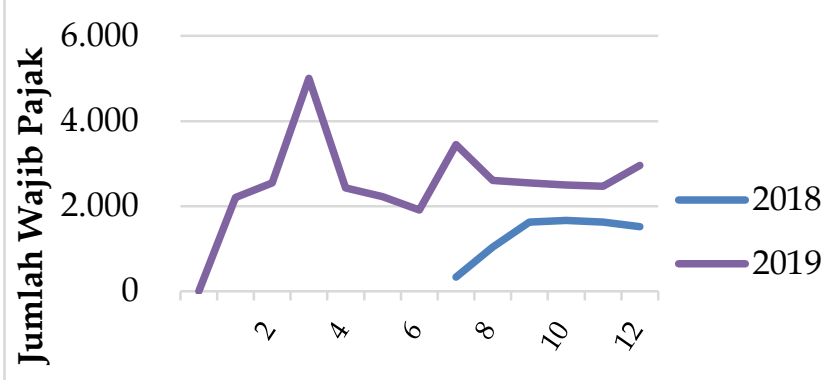

Berdasarkan Grafik 4.1, jumlah Wajib Pajak yang melakukan pembayaran PPh Final PP 23 untuk Wajib Pajak Orang Pribadi mengalami peningkatan yang cukup signifikan. Jumlah terbanyak Wajib Pajak Orang Pribadi yang melakukan pembayaran berada pada bulan Maret 2019. Menurut penjelasan Account Representative (AR), Bapak Tumpal Junianto hal tersebut disebabkan karena pada saat tersebut adalah masa penyampaian SPT Tahunan Orang Pribadi. Hal tersebut menyebabkan banyak AR mengirimkan surat himbauan kepada Wajib Pajak agar melaporkan SPT Tahunan. Kemudian Wajib Pajak akan datang ke kantor pajak dalam rangka edukasi pelaporan SPT Tahunan. Pada saat itu, AR akan mengecek apakah Wajib Pajak sudah melakukan pembayaran untuk tahun pajak tersebut. Apabila Wajib Pajak belum membayar, maka AR akan mengarahkan Wajib Pajak untuk melakukan pembayaran terlebih dahulu kemudian melaporkan SPT Tahunan. Oleh karena itu jumlah pada bulan Maret 2019 menjadi jumlah terbanyak sedangkan untuk bulan berikutnya akan mengalami penurunan. Namun secara keseluruhan, terjadi peningkatan yang cukup signifikan dari tahun 2018 .
Jumlah Wajib Pajak Badan yang melakukan pembayaran PPh Final PP 23 Tahun di KPP Pratama Kabanjahe dapat digambarkan pada Grafik 4.2.

Grafik 4.2 Wajib Pajak Badan yang Melakukan Pembayaran PPh Final PP 23 di KPP Pratama Kabanjahe

Berdasarkan grafik tersebut, dapat dilihat bahwa jumlah Wajib Pajak yang melakukan pembayaran mengalami peningkatan. Sama seperti Wajib Pajak Orang Pribadi, jumlah Wajib Pajak yang melakukan pembayaran mengalami peningkatan yang sangat signifikan pada bulan April 2019. Hal tersebut bertepatan dengan jangka waktu pelaporan SPT Tahunan Badan yang jatuh pada 30 April. Setelah itu, jumlah Wajib Pajak mengalami penurunan kembali namun kembali mengalami peningkatan sampai dengan akhir tahun 2019. Berdasarkan grafik tersebut, dapat juga dilihat bahwa tren jumlah Wajib Pajak Badan yang melakukan pembayaran antara tahun 2018 dan 2019 memiliki kemiripan

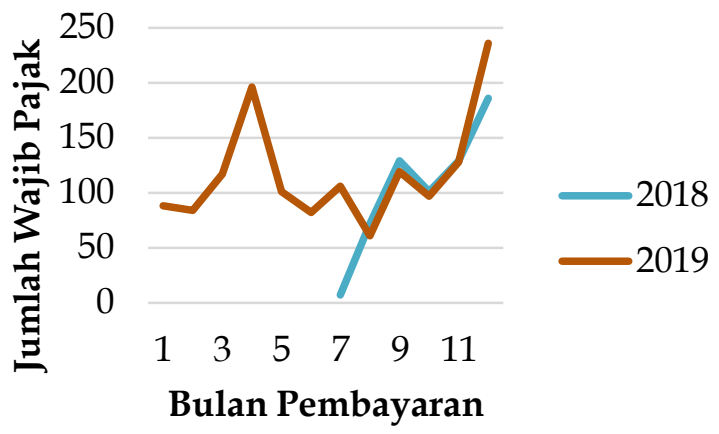

dari segi jumlah sehingga grafik tahun 2018 dan tahun 2019 menjadi mirip.

Tren jumlah Wajib Pajak yang melakukan pembayaran PP 46 dalam Grafik 4.3.

Grafik 4.3 Data Wajib Pajak yang Melakukan Pembayaran PP 46 di KPP Pratama Kabanjahe 


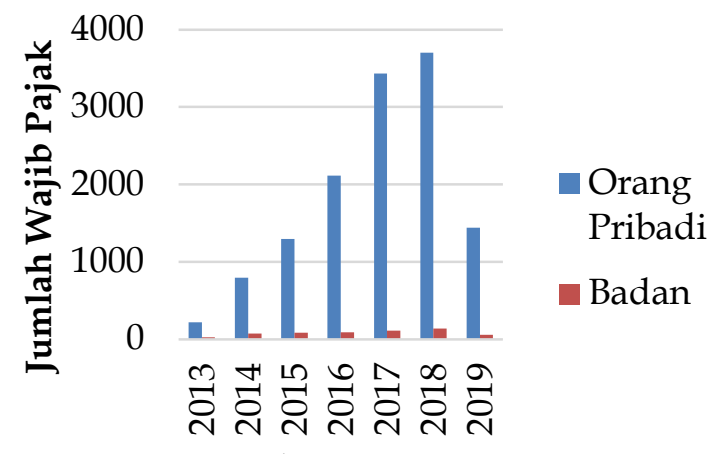

Tahun Bayar

Berdasarkan grafik tersebut, dapat dilihat bahwa jumlah Wajib Pajak yang melakukan pembayaran PP 46 mengalami peningkatan sejak tahun 2013 yaitu saat peraturan tersebut disahkan. Pada tahun 2018, grafik tersebut masih mengalami peningkatan namun tidak sebanyak dari tahun tahun sebelumnya. Hal tersebut menurut Bapak Tumpal Junianto disebabkan karena setoran setelah masa Juli 2018 merupakan setoran atas PPh Final PP 23 sehinga jumlahnya menjadi berkurang. Selanjutnya untuk pembayaran pada tahun 2019 merupakan pembayaran yang dilakukan Wajib Pajak atas masa pajak 2018 atau sebelumnya, sehingga menyebabkan turunnya grafik.

Selain membandingkan jumlah Wajib Pajak yang melakukan pembayaran, efektivitas PP 23 di KPP Pratama Kabanjahe dapat dilihat melalui jumlah penerimaan per masa pajak, per jenis Wajib Pajak melalui Grafik 4.4

Grafik 4.4. Penerimaan PPh Final PP 23 Wajib Pajak Orang Pribadi di KPP Pratama Kabanjahe

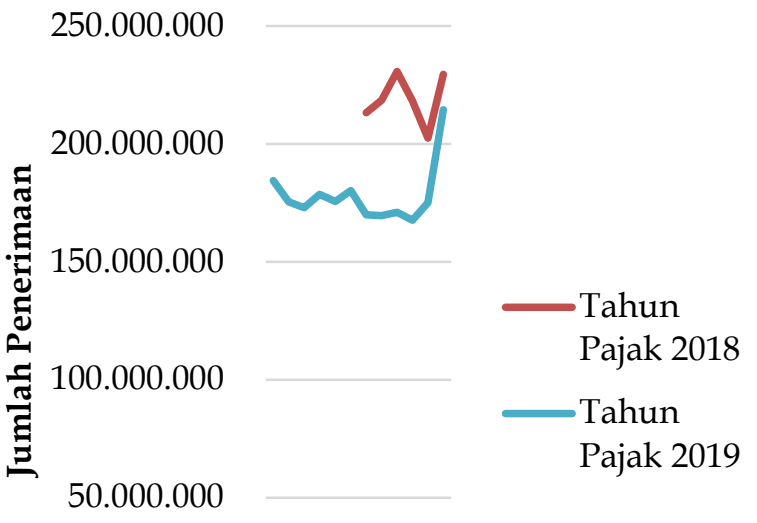

0

$\begin{array}{llll}1 & 4 & 7 & 10\end{array}$

Masa Pajak

Berdasarkan grafik tersebut, jumlah penerimaan tahun 2018 lebih besar dibandingkan dengan tahun 2019. Menurut Bapak Tumpal Junianto, hal tersebut terjadi karena pada tahun 2018 masih banyak Wajib Pajak yang belum mengetahui perubahan peraturan, sehingga Wajib Pajak masih melakukan penghitungan pajak terutang dengan menggunakan tarif $1 \%$. Sedangkan pada tahun 2019, jumlah Wajib Pajak yang mengetahui tentang perubahan peraturan meningkat sehingga Wajib Pajak sudah menggunakan tarif $0,5 \%$ dalam menghitung pajak terutang. Hal tersebut berdampak pada turunnya jumlah penerimaan PPh Final PP 23. Adapun jumlah penurunan penerimaan sekitar $20 \%$. Setelah itu, penerimaan sepanjang tahun pajak 2019 mengalami penurunan yang cukup sedikit dan relatif stabil kemudian pada akhir tahun 2019 mengalami peningkatan yang cukup signifikan di angka Rp 214,577,829.

Berbeda dengan Orang Pribadi, penerimaan PPh Final PP 23 Wajib Pajak Badan mengalami peningkatan yang di gambarkan pada Grafik 4.5

Grafik 4.5 Penerimaan PPh Final PP 23 Wajib

Pajak Badan di KPP Pratama Kabanjahe 
terjadi perubahan aturan yang menyebabkan

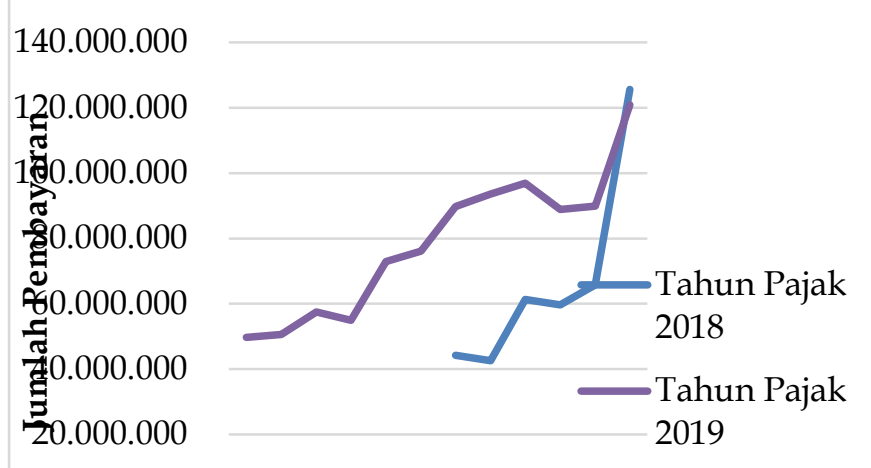

0

123456789101112

Masa Pajak

Berdasarkan grafik tersebut, dapat dilihat bahwa jumlah penerimaan PPh Final PP 23 Wajib Pajak Badan mengalami peningkatan sejak masa Juli 2018 hingga Desember 2018. Pada masa Desember 2018 mengalami peningkatan yang cukup signifikan dikarenaan adanya jumlah pembayaran dari beberapa Wajib Pajak yang cukup besar. Kemudian pada masa Januari 2019 kembali terjadi penurunan pembayaran, namun sepajang tahun 2019 secara umum mengalami peningkatan yang signifikan.

Untuk membandingkan dengan penerimaan PPh Final PP 46, maka dapat digambarkan dalam grafik sebagai berikut.

Grafik 4.6 Penerimaan PPh Final PP 46 di KPP Pratama Kabanjahe

Penerimaan dari masa Juli 2018 sampai dengan Desember 2018 akan masuk ke penerimaan PP 23. Pada tahun 2018, penerimaan

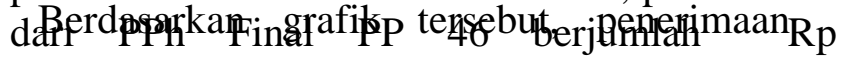

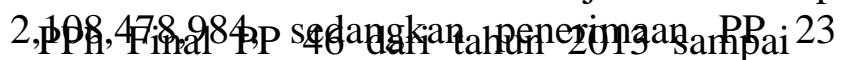
untuk tahun 2018 sebesar Rp 1,713,143,023. Jika

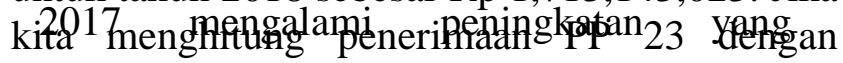

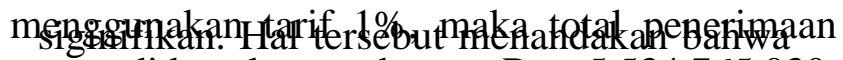
yang didapatkan sebesar $\mathrm{Rp} 5,534,765,030$.

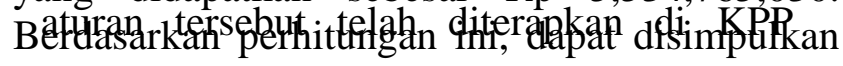

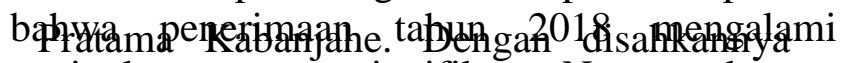
peningkatan yang signifikan. Namun, karena aturan baru yaitu PP 23, maka menyebabkan

Jurnal Âkuntansi dan Pajak, ISSN1412-629X I E-ISSN2579-3055 dalam Grafik 4.7. Pratama Kabanjahe turunnya tarif pajak menjadi $0,5 \%$ menyulitkan perhitungan efektivitas dari PP 23 tersebut.

Selain menghitung penerimaan perpajakan, menghitung tingkat kepatuhan Wajib Pajak dapat digunakan dalam menentukan apakah Wajib Pajak telah melaksanakan kewajiban perpajakannya atau tidak. Dalam Laporan Kinerja Direktorat Jenderal Pajak (2019:40), persentase kepatuhan Wajib Pajak Badan dan Orang Pribadi Non Karyawan terdiri dari 2 (dua) aspek pengukuran, yaitu persentase tingkat kepatuhan formal Wajib Pajak Badan dan OP Non Karyawan, dan persentase jumlah Wajib Pajak Badan dan OP Non Karyawan yang melakukan pembayaran. Oleh karena itu, tingkat kepatuhan dapat dijadikan di

T

a:

$\mathrm{d}$

$\mathrm{m}$

ji

$\mathrm{p}$

$\mathrm{m}$

U

$\mathrm{p}$

$\mathrm{P}$

m elf ng an ak sai an PT ah an ak. im wajib pajak pada Tabel II.5 dapat disajikan

Grafik 4.7 Kepatuhan Wajib Pajak KPP 


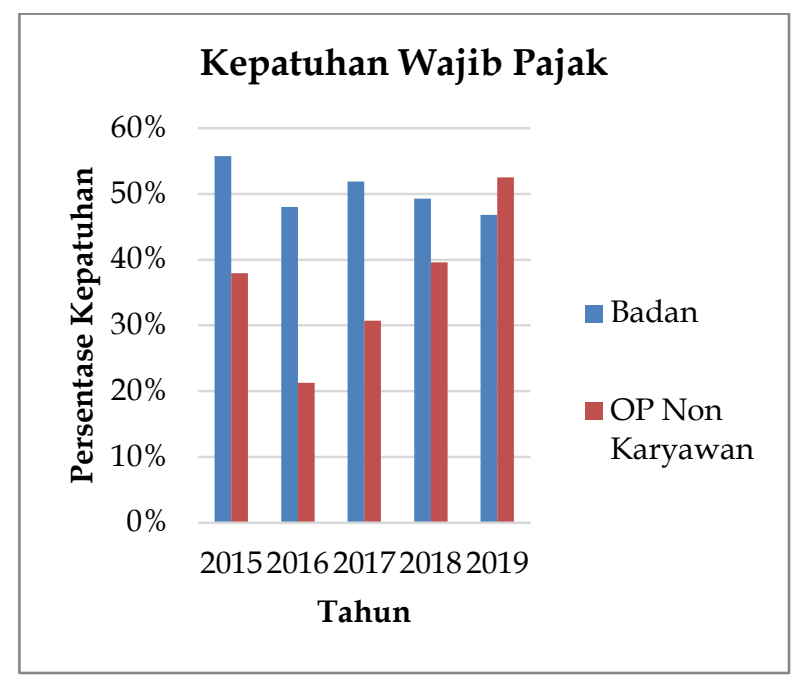

Berdasarkan Grafik 4.7, tingkat kepatuhan Wajib Pajak dapat dibagi menjadi tingkat kepatuhan Wajib Pajak Orang Pribadi Non Usahawan, dan Badan. Dalam menghitung tingkat kepatuhan menggunakan data penerimaan SPT Tahunan dibandingkan dengan data Wajib Pajak Wajib SPT. Pada grafik tersebut, terlihat persentase kepatuhan Wajib Pajak Badan secara keseluruhan memiliki tren yang naik-turun sedangkan untuk Orang Pribadi Non Usahawan pada tahun 2016 mengalami penurunan namun setelah itu mengalami kenaikan yang cukup signifikan. Untuk membandingkan efektifitas kepatuhan Wajib Pajak dengan aturan PP 46 dibandingkan dengan PP 23 dapat dilakukan dengan membandingkan tingkat kepatuhan Wajib Pajak sebelum tahun 2018 dan setelah tahun 2018 yaitu sebelum pada saat PP 46 masih berlaku dengan pada saat penerapan PP 23. Pada kategori Wajib Pajak Orang Pribadi Non Usahawan, terjadi peningkatan baik pada saat PP 46 berlaku maupun saat PP 23 berlaku. Sedangkan untuk kategori Wajib Pajak Badan, persentase kepatuhan Wajib Pajak mengalami penurunan dari tahun 2017 sampai 2019. Hal ini disebabkan terjadinya peningkatan Wajib Pajak Badan yang wajib SPT namun tidak dibarengi dengan kenaikan realisasi pelaporan SPT Tahunan. Hal ini menunjukkan bahwa perubahan peraturan PP 46 menjadi PP 23 tidak memiliki pengaruh signifikan terhadap kepatuhan Wajib Pajak Badan.

\subsection{Pembahasan}

Masalah terkait penerapan PP 23 Tahun 2018 di KPP Pratama Kabanjahe

Dalam rangka menerapkan aturan baru di masyarakat, perlu dilakukan kegiatan yang bertujuan untuk memperkenalkan aturan tersebut agar Wajib Pajak dapat memahami aturan tersebut. Menurut Hendri (2018), KPP sebagai institusi terdepan dalam kegiatan administrasi perpajakan sangat mempengaruhi arus informasi yang disampaikan kepada Wajib Pajak. Direktur Jenderal Pajak memberikan beberapa poin terkait indikator sosialisasi dimana kegiatan tersebut diharapkan dapat memberikan kesadaran dan rasa peduli terhadap pajak yang dimodifikasi dari pengembangan program pelayanan perpajakan (Winerungan, $2013: 30$ ), yaitu

a. Penyuluhan; sosialisasi yang dibentuk oleh Direktorat Jenderal Pajak dengan menggunakan media massa atau media elektronik menyangkut penyuluhan peraturan perpajakan kepada Wajib Pajak.

b. Berdiskusi langsung dengan Wajib Pajak dan tokoh masyarakat; Direktorat Jenderal Pajak memberikan komunikasi dua arah antara Wajib Pajak dengan petugas pajak (fiskus) maupun masyarakat yang dianggap memberikan pengaruh atau dipandang oleh masyarakat sekitarnya.

c. Informasi langsung dari petugas (fiskus) ke Wajib Pajak; petugas pajak memberikan informasi secara langsung kepada Wajib Pajak tentang peraturan perpajakan.

d. Pemasangan billboard; pemasangan spanduk atau billboard pada tempat yang strategis, sehingga mudah dilihat oleh masyarakat. Berisi pesan singkat berupa kutipan perkataan, pernyataan dengan bahasa penyampaian yang mudah dipahami.

Berdasarkan hal tersebut, Seksi Ekstensifikasi dan Penyuluhan beserta Seksi Pengawasan dan Konsultasi melakukan beberapa kegiatan dengan maksud agar setiap Wajib Pajak mengerti dan memahami serta melaksanakan PP 23 dengan baik.

a. Sosialisasi kepada Usaha Mikro, Kecil, Menengah (UMKM); menurut Ananda dkk (2015:6) salah satu faktor yang mempengaruhi kepatuhan Wajib Pajak adalah sosialisasi. Oleh karena itu sosialisasi menjadi hal yang cukup penting sebagai sarana pemberian informasi kepada masyarakat. Berdasarkan hasil wawancara dengan Bapak Sabar Johannes, Seksi Ekstensifikasi dan Penyuluhan telah melaksanakan kegiatan sosialisasi kepada Wajib Pajak khususnya UMKM sebagai 
upaya untuk memperkenalkan PP 23 kepada masyarakat. Kegiatan sosialisasi ini dilaksanakan dengan menggandeng beberapa organisasi atau lembaga masyarakat agar semakin menarik minat Wajib Pajak untuk mengikuti kegiatan sosialisasi. Pelaksanaan sosialisasi ini dibantu dengan program Business Delevopment Services (BDS) yang sudah terlebih dahulu dijalankan di KPP Pratama Kabanjahe. Program BDS adalah salah satu strategi pembinaan dan pengawasan kepada Wajib Pajak UMKM dalam membina dan mendorong pengembangan usahanya secara berkesinambungan yang bertujuan untuk meningkatkan kesadaran (awareness), keterikatan (engagement), dan kepatuhan (compliance) terhadap pajak. Program ini telah melakukan pemetaan terhadap Wajib Pajak UMKM, sehingga kegiatan sosialisasi yang diadakan menjadi lebih terpusat.

b. Pemberian Leaflet dan Brosur terkait aturan PP 23 Tahun 2018; leaflet dan brosur diberikan kepada Wajib Pajak yang datang ke kantor untuk melakukan pembayaran atau pelaporan. Leaflet dan brosur berisi informasi yang singkat, padat, dan jelas serta dilengkapi dengan nomor telepon yang dapat dihubungi oleh Wajib Pajak apabila memiliki pertanyaan seputar aturan tersebut.

c. Pemasangan spanduk di berbagai tempat atau kantor pemerintahan ; seksi Ekstensifikasi dan Penyuluhan bekerja sama dengan pemerintah daerah dalam rangka memasang spanduk di beberapa kantor pemerintah seperti Kantor Bupati, pusat pasar dan juga di pinggir jalan.

d. Pemberian informasi berupa konsultasi kepada calon Wajib Pajak Baru yang hendak memiliki NPWP; kegiatan ini dilakukan ketika Wajib Pajak mendatangi kantor untuk melakukan pendaftaran NPWP. Account Representative (AR) akan memberikan konsultasi kepada calon Wajib Pajak berupa kewajiban apa saja yang harus dilaksanakan. Apabila calon Wajib Pajak merupakan usahawan, maka AR akan menjelaskan tentang PP 23.

e. Mengirimkan pesan singkat kepada Wajib Pajak; Seksi Ekstensifikasi dan Penyuluhan memberikan pengumuman melalui pesan singkat kepada Wajib Pajak dalam rangka memberikan informasi atas terjadinya perubahan peraturan dan masa berlaku aturan tersebut.

Semua kegiatan tersebut dilakukan dengan tujuan agar Wajib Pajak di wilayah kerja KPP Pratama Kabanjahe dapat mengerti dan memahami PP 23 secara menyeluruh. Namun dalam prakteknya, terdapat beberapa hambatan atau permasalahan terkait penerapan aturan tersebut yaitu:

a. Wajib Pajak tidak menghadiri kegiatan sosialisasi; tantangan dan hambatan yang paling utama dalam pelaksanaan sosialisasi yang dilaksanakan oleh Seksi Ekstensifikasi dan Penyuluhan adalah ketidakhadiran Wajib Pajak. Banyak Wajib Pajak yang tidak dapat menghadiri kegiatan sosialisasi di kantor karena daerah domisili dari sebagian besar masyarakat cukup jauh dari tempat sosialisasi. Untuk menghadiri kegiatan sosialisasi yang dilaksanakan di KPP Pratama Kabanjahe, Wajib Pajak harus meluangkan waktu satu hari penuh. Hal ini menyebabkan Wajib Pajak enggan untuk meninggalkan kegiatan mereka baik berkebun atau berjualan dibandingkan dengan menghadiri kegiatan sosialisasi.

b. Resistensi dari Wajib Pajak; masih banyak wajib pajak yang memiliki pola pikir bahwa membayar pajak bukanlah suatu hal yang wajib dilakukan. Hal inilah yang menyebabkan Wajib Pajak cenderung tidak jujur ketika berkonsultasi dengan AR dalam rangka menghitung kewajiban perpajakannya. Selain itu, banyak Wajib Pajak yang membuat NPWP hanya sebagai syarat untuk melalukan pengurusan pinjaman ke Bank. Sehingga ketika Wajib Pajak selesai mendaftar, mereka melupakan kewajiban perpajakannya.

c. Kurangnya pengetahuan Wajib Pajak atas teknologi; kemajuan teknologi yang menyebabkan kemajuan di bidang pembayaran pajak telah memberikan kemudahan kepada sebagian besar masyarakat. Pada saat ini, Direktoral Jenderal Pajak telah memiliki layanan online yang dapat mempermudah Wajib Pajak dalam melaksanakan kewajiban perpajakan khususnya pembayaran (Bandiyono, Septiana, 2018, 20). Salah satu layanan dari DJP Online ini adalah e-Billing pajak. 
Pembayaran pajak kini telah menggunakan sistem E-billing yaitu sistem pembayaran pajak dengan menggunakan kode yang telah dibuat secara sistem sehingga dalam melakukan pembayaran pajak tidak perlu mengisi Surat Setoran Pajak (SSP). Namun ditengah kemudahan tersebut, masih terdapat domisili Wajib Pajak yang belum mendapatkan jangkauan internet, sehingga ketika akan melakukan pembayaran melalui E-billing harus tetap datang ke kantor atau dibantu oleh pihak lain. KPP Pratama KABANJAHE berusaha mengatasi masalah tersebut dengan cara membuat layanan SMS Center, dimana Wajib Pajak yang ingin membuat kode billing dan melakukan pembayaran pajak dapat mengirimkan pesan singkat ke nomor SMS Center tersebut. Kemudian pegawai dari Seksi Ekstensifikasi akan mengirimkan kode billing kepada Wajib Pajak. Walaupun demikian, layanan ini memiliki kekurangan apabila terjadi lonjakan permintaan kode billing.

\section{KESIMPULAN}

4.1. Kesimpulan

Penerapan PP 23 Tahun 2018 di KPP Pratama Kabanjahe dapat dikatakan cukup efektif. Hal tersebut berdasarkan data Wajib Pajak yang melakukan pembayaran PPh Final PP 23 yang mengalami kenaikan yang cukup signifikan. Selain itu terjadi kenaikan setoran PPh Final PP 23 sepanjang tahun 2018 ke tahun 2019. Walaupun terjadi penurunan jumlah setoran dibandingkan dengan tahun sebelumnya, namun hal tersebut terjadi karena terjadinya penurunan tarif dari $1 \%$ menjadi $0,5 \%$. Walaupun penerapan PP 23 di KPP Pratama sudah cukup efektif, namun hal tersebut tidak mempengaruhi persentase tingkat kepatuhan Wajib Pajak khususnya Wajib Pajak Badan. Sedangkan persentase tingkat kepatuhan Wajib Pajak Orang Pribadi Non Usahawan mengalami peningkatan dari tahun 2016 sampai tahun 2019, sehingga dapat disimpulkan aturan tersebut cukup efektif dalam meningkatkan tingkat kepatuhan Wajib Pajak Orang Pribadi.

Selain itu masih terdapat permasalahan yang menghambat penerapan PP 23 Tahun 2018 di KPP Pratama Kabanjahe, namun KPP Pratama Kabanjahe berusaha untuk mengatasi permasalahan tersebut dengan berbagai program.

\subsection{Saran}

Berdasarkan hasil uraian diatas disimpulkan bahwa penerapan aturan PP 23 di KPP Pratama Kabanjahe sudah cukup efektif, namun terdapat beberapa masalah yang menghambat hal tersebut. Agar penerapan PP 23 di KPP Pratama Kabanjahe dapat semakin efektif, maka perlu dilaksanakan kegiatan-kegiatan yang bertujuan agar Wajib Pajak mengetahui, memahami dan memiliki keinginan untuk ikut serta dalam pembangunan negara melalui pajak. Selain itu, KPP Pratama Kabanjahe harus dapat menyingkirkan segala halangan dan menjembatani Wajib Pajak yang memiliki permasalahan di bidang tekonologi untuk menghalangi mereka untuk melaksanakan kewajiban perpajakannya. Kegiatan-kegiatan yang dapat dilakukan adalah:

a. Melakukan jenis pendekatan yang sesuai kepada Wajib Pajak sehingga meningkatkan tingkat kepercayaan dari Wajib Pajak. Apabila Wajib Pajak memiliki tingkat kepercayaan yang tinggi, maka mereka akan memberikan informasi tentang penghasilannya dengan lebih transparan dan jujur.

b. Merangkul setiap jenis stakeholder sehingga bisa menjadi perpanjangan tangan Direktorat Jenderal Pajak (KPP) dalam menggugah kesadaran Wajib Pajak dengan keyakinan bahwa pembangunan nasional adalah tanggung jawab bersama dengan melakukan pembayaran pajak sesuai dengan keadaan sebenarnya.

c. Menggandeng tokoh atau organisasi masyarakat dalam rangka menyampaikan sosialisasi secara bersama-sama sehingga berbagai informasi dapat lebih diterima oleh Wajib Pajak.

d. Mengembangkan layanan yang sudah ada yaitu SMS Center dengan memanfaatkan sistem operasi sehingga layanan tersebut dapat berjalan secara otomatis.

\section{IMPLIKASI DAN KETERBATASAN}

5.1. Implikasi

1. Berdasarkan hasil simpulan diatas, efektivitas penerapan PP 23 di KPP Pratama Kabanjahe sudah cukup efektif sehingga perlu 
dipertahankan dan ditingkatkan dalam rangka mencapai penerimaan pajak

2. Perlu dilakukan penelitian lebih lanjut tentang tata cara sosialisasi maupun penyuluhan perpajakan kepada Wajib Pajak sehingga meningkatkan kesadaran Wajib Pajak dalam memenuhi kewajiban perpajakannya.

5.2. Keterbatasan

Penelitian ini telah diusahakan untuk dilaksanakan sesuai dengan prosedur yang seharusnya, namun demikian masih memiliki keterbatasan yaitu:

3. Terdapat cara lain yang dapat digunakan dalam menentukan efektivitas sebuah peraturan yang tidak dicakup didalam penelitian ini seperti kuisioner dan wawancara kepada Wajib Pajak.

4. Tidak melakukan survey kepada Wajib Pajak sehingga penelitian ini masih kurang menunjukkan keadaan yang sesungguhnya di masyarakat.

\section{REFERENSI}

Bandiyono, A., \& Septiana, B. F. 2018. Pelaksanaan E-Billing Pajak Pada Kantor Pelayanan Pajak. Jurnal Kebijakan Publik, 9(1): 19-26.

Direktorat Jenderal Pajak. 2019. Laporan Kinerja Direktorat Jenderal Pajak Tahun 2018. DJP. Jakarta.

Hendri. 2018. Implementasi Sosialisasi Peraturan Pemerintah No. 23 Tahun 2018 Bagi Pelaku Usaha Mikro, Kecil dan Menengah (UMKM). Jurnal Vokasi Indonesia, 6(2) : 53-58.

Jotopurnomo, C., \& Mangoting, Y. 2013. Pengaruh kesadaran wajib pajak, kualitas pelayanan fiskus, sanksi perpajakan, lingkungan wajib pajak berada terhadap kepatuhan wajib pajak orang pribadi di Surabaya. Tax \& Accounting Review, 1(1) :49.

Kementerian Keuangan.2009.Lebih Dekat dengan Pajak (2009). Indonesia. Kementerian Keuangan.

Peraturan Pemerintah Republik Indonesia Nomor 23 Tahun 2018 tentang Pajak Penghasilan dari Usaha yang Diterima atau Diperoleh
Wajib Pajak yang Memiliki Peredaran Bruto Tertentu.

Peraturan Pemerintah Republik Indonesia Nomor 46 Tahun 2013 tentang PajakPenghasilan atas Penghasilan Dari Usaha yang Diterima atau DiperolehWajib Pajak yang Memiliki Peredaran Bruto Tertentu.

Siti Kurnia Rahayu. 2010.Perpajakan Indonesia: Konsep dan Aspek Formal Yogyakarta: Penerbit Graha Ilmu.

Suryani, W., Maslichah, M., \& Junaidi, J. 2019. Pengaruh Pengalihan PP 462013 Menjadi PP 232018 Terhadap Tingkat Pertumbuhan Wajib Pajak UMKMdan Penerimaan PPh Pasal 4 Ayat (2) Di KPP Pratama Pasuruan. Jurnal Ilmiah Riset Akuntansi, 8(02).

Tarjo, T., \& Kusumawati, I. 2006. Analisis Perilaku Wajib Pajak Orang Pribadi terhadap Pelaksanaan Self Assessment System: Suatu Studi di Bangkalan. Jurnal Akuntansi dan Auditing Indonesia, 10(1)

Winerungan, Lidya Oktaviane. 2013. Sosialisasi Perpajakan, Pelayanan Fiskus dan Sanksi Perpajakan terhadap kepatuhan WPOP di KPP Manado dan KPP Blitung. Jurnal EMBA Vol. 1 No 3. 